\title{
Effects of different drying methods on the bioactive compounds and antioxidant properties of edible Centaurea (Centaurea cyanus) petals
}

\section{Efeito de diferentes métodos de secagem nos compostos bioactivos e propriedades} antioxidantes de pétalas de Centáurea (Centaurea cyanus)

\author{
Luana Fernandes ${ }^{1,2,3}$, Susana Casal $^{2}$, José Alberto Pereira1 ${ }^{1}$ Jorge Alexandre Saraiva ${ }^{3}$, Elsa Ramalhosa ${ }^{1 *}$ (D \\ 1 Instituto Politécnico de Bragança, Escola Superior Agrária, Centro de Investigação de Montanha (CIMO), Bragança - Portugal \\ 2 Universidade do Porto, Faculdade de Farmácia, Laboratório de Bromatologia e Hidrologia (LAQV@REQUIMTE), Porto - Portugal \\ ${ }^{3}$ Universidade de Aveiro, Química Orgânica, Produtos Naturais e Agro-alimentares (QOPNA), Aveiro - Portugal
}

\section{*Corresponding Author}

Elsa Ramalhosa, Instituto Politécnico de Bragança, Escola Superior Agrária, Centro de Investigação de Montanha (CIMO), Campus de Santa Apolónia, CEP: 5300-253, Bragança - Portugal, e-mail: elsa@ipb.pt

Cite as: Effects of different drying methods on the bioactive compounds and antioxidant properties of edible Centaurea (Centaurea cyanus) petals. Braz. J. Food Technol., v. 21, e2017211, 2018.

Received: Dec. 04, 2017; Accepted: Mar. 28, 2018

\section{Abstract}

The present study aimed to evaluate the effects of hot-air convective drying, shade drying and freeze-drying on the bioactive compounds and antioxidant activity of Centaurea (Centaurea cyanus L.) petals, as well as on several of their physicochemical properties. All the dried samples showed different appearances as compared to fresh petals, with lower titratable acidity, lower carotenoids and hydrolysable tannins contents, and greater antioxidant activity. Of the drying methods, shade drying presented the highest values for monomeric anthocyanins, flavonoids, hydrolysable tannins, total reducing capacity and antioxidant activity. By contrast, greater losses were observed as a result of hot-air convective drying. Thus shade drying is a highly promising process that should be considered as a suitable drying method for Centaurea petals.

Keywords: Centaurea petals; Hot-air convective drying; Shade drying; Freeze-drying; Bioactive compounds; Antioxidant activity.

\section{Resumo}

No presente trabalho pretendeu-se avaliar o efeito da secagem por convecção com ar quente, secagem à sombra e liofilização sobre compostos bioactivos e actividade antioxidante de pétalas de centáurea, bem como em algumas propriedades físico-químicas. Todas as amostras desidratadas apresentaram uma aparência diferente das frescas, menor acidez titulável e menores teores de carotenóides e taninos hidrolisáveis. Por outro lado, as amostras secas apresentaram uma maior actividade antioxidante. Entre os métodos de secagem, a secagem à sombra apresentou os maiores valores de antocianinas monoméricas, flavonóides, taninos hidrolisáveis, capacidade redutora total e actividade antioxidante. Pelo contrário, as maiores perdas foram observadas com ar quente. Assim, a secagem à sombra é um processo bastante promissor que deve ser considerado como um método adequado para desidratar pétalas de centáurea.

Palavras-chave: Pétalas de Centáurea; Secagem por convecção com ar quente; Secagem à sombra; Liofilização; Compostos bioactivos; Actividade antioxidante.

\section{Introduction}

The Centaurea (Centaurea cyanus L.) flower, also known as blue cornflower or bachelor's button, grows as a wild and common garden plant throughout Europe (CHIRU, 2009). Due to its intense blue flowers it is used as an ornamental plant, for colouring sugar and confectionaries, in teas and salads and to garnish dishes (CHIRU, 2009; CHAITANYA, 2014). Several therapeutic activities have also been attributed to Centaurea flowers, including the treatment of indigestion, 
gallbladder dysfunction, kidney regulation, menstrual disorder regulation, increasing immunity and for the efficient cleaning of wounds (CHIRU, 2009; LIM, 2014). However, fresh Centaurea flowers are difficult to store since the petals show visible signs of deterioration just a few days after harvest, even under refrigeration. Up to now, no guidelines have been established for the storage of edible flowers, and few studies have been carried out to determine which factors limit their quality (KOU et al., 2012).

Drying is the most common post-harvest method for the preservation of plants (BATRAS, 2015) and fruits (SADLER, 2016). This technology can be used to obtain products that are easily processed, can be stored for long periods and can be used conveniently in the manufacture of formulated foods. Drying methods decrease the water-related activities of plants, and consequently inhibit the growth of microorganisms while decreasing the rate of the biochemical reactions, thus extending the shelf life of the products at room temperature (HAMROUNI-SELLAMI et al., 2013). Furthermore, these processes are more economical with respect to storage and transport costs, since dried flowers occupy less space, weigh less and do not require refrigeration. However, knowledge concerning the application of drying methods to edible flowers remains insufficient (ABASCAL et al., 2005). Several studies have been carried out with marigold flowers (Tagetes erecta L.) (SIRIAMORNPUN et al., 2012), purple coneflower (Echinacea purpurea (L.) Moench) (LIM, 2014; KIM et al., 2000), roses (Rosa $\times$ hybrida L.), carnations (Dianthus caryophyllus L.) (CHEN et al., 2000), daylilies (Hemerocallis disticha Donn.) (TAI; CHEN, 2000) and black locust flowers (Robinia pseudoacacia L.) (Jl et al., 2012), but none have involved Centaurea petals. Thus the aim of this work was to investigate the effects of three different drying methods (hot-air convective drying, shade-drying, and freeze-drying) on the bioactive compounds of Centaurea petals, including the monomeric anthocyanins, carotenoids, flavonoids and hydrolysable tannin contents, as well as on the total reducing capacity and antioxidant activity (DPPH radical scavenging activity and reducing power), and on several physicochemical properties, in order to identify the best method to preserve the bioactive richness and quality of Centaurea petals.

\section{Material and methods}

\subsection{Fresh petals}

Approximately $1 \mathrm{~kg}$ of fully developed fresh Centaurea flowers was collected from different plants at the greenhouse of the School of Agriculture, Polytechnic Institute of Bragança, Portugal. Immediately after harvesting, the fresh flowers were transported to the laboratory under refrigeration and the petals separated from the remaining parts of the flowers.

\subsection{Drying methods}

The fresh petals were dried using three methods, as described below.

1. Hot-air convective drying: The petals were distributed uniformly as thin layers on trays and dried in an oven at $50^{\circ} \mathrm{C}$ (Memmert, Schwabach) for 1,2, 3 or 4 hours. This temperature was chosen because it is commonly found in similar studies on drying flowers and herbs (MAO et al., 2006; BALLADIN; HEADLEY, 1999; CHEN et al., 2000). The relative humidity and temperature were controlled in the different sections of the hot-air convective oven using portable thermo-hygrometers (Hanna Instruments, HI 9564, Woonsocket) and digital thermometers (Hanna Instruments, HI 98509, Woonsocket), respectively. The relative humidity was maintained constant at $4.3 \% \pm 1.2 \%$ and the temperature at $49.6{ }^{\circ} \mathrm{C} \pm 2.4{ }^{\circ} \mathrm{C}$ throughout the experiments;

2. Shade drying: The Centaurea petals were distributed uniformly as thin layers on trays and dried in the dark for 3 days at room temperature $\left(22^{\circ} \mathrm{C}\right)$, with a relative humidity of $41.0 \% \pm 0.4 \%$;

3. Freeze-drying: The Centaurea petals were frozen at $\left(-18{ }^{\circ} \mathrm{C}\right)$ and then freeze-dried at $-120^{\circ} \mathrm{C}$ (Scanvac, Coolsafe, Lynge, Denmark) for $24 \mathrm{~h}$.

Each treatment was carried out in triplicate. The drying times were established in order to attain a water activity $\left(\mathrm{a}_{\mathrm{w}}\right)$ below 0.5 .

\subsection{Weight loss, moisture content, water activity, $\mathrm{pH}$ and titratable acidity}

The weight loss $(\mathrm{WL})$ was determined according to Equation 1:

$$
\mathrm{WL}=\frac{\mathrm{M}_{0}-\mathrm{M}}{\mathrm{M}_{0}} \times 100
$$

where: $M_{0}$ was the initial mass of fresh Centaurea petals before drying and $M$ the mass of Centaurea petals after drying.

The weight was determined using a digital balance (Kern ACJ/ACS, Balingen, Germany) and the moisture content from the weight loss at $105^{\circ} \mathrm{C}$ to constant weight (BOLAND; CUNNIFF, 1999). The water activity $\left(a_{w}\right)$ was determined using a portable water-activity meter (Novasina, LabSwift-aw, Lachen, Switzerland). To determine the titratable acidity (TA), a $0.5 \mathrm{~g}$ sample was homogenized in $50 \mathrm{~mL}$ of distilled water using an Ultra-Turrax homogenizer (IKA, Werke, Germany), filtered (GAITHERSBURG; HORWITZ, 1990), and $10 \mathrm{~mL}$ of the filtrate titrated with $0.01 \mathrm{~N} \mathrm{NaOH}$, using phenolphthalein as the indicator. The results were expressed as $\mathrm{g}$ citric acid/100 $\mathrm{g}$ of dry weight (DW). 


\subsection{Carotenoids}

The carotenoid content was determined according to the method used by Aquino-Bolaños et al. (2013). One gram of dried petals, subjected to the different drying methods, as well as a fresh sample (control), were extracted twice with $20 \mathrm{~mL}$ of an acetone:hexane solution $(1: 1, \mathrm{v} / \mathrm{v})$. The extracts were each placed in a separation funnel, to which $200 \mathrm{~mL}$ of distilled water were added to eliminate the acetone. The acetone-free phase was mixed with $5 \mathrm{~g}$ of anhydrous sodium sulphate to eliminate any residual water; and the remaining solution filtered and the volume completed to 100 $\mathrm{mL}$ with hexane. The carotenoid content was determined by reading the absorbance at $450 \mathrm{~nm}$, using a calibration curve of $\beta$-carotene in hexane $(0.22-8.8 \mu \mathrm{g} / \mathrm{mL})$. The results were expressed in $\mu \mathrm{g} \beta$-carotene/g DW.

\subsection{Preparation of the extracts for the analysis of polar bioactive compounds and antioxidant activity}

Dried powdered samples obtained by the different drying methods $(1 \mathrm{~g})$, as well as a fresh sample (control), were extracted with $50 \mathrm{~mL}$ of water:acetone $(6: 4 ; \mathrm{v} / \mathrm{v})$ at $40{ }^{\circ} \mathrm{C}$ for 30 min with agitation (IKA, RCT Model B, Staufen, Germany) at a frequency of $1000 \mathrm{rpm}$ (LI et al., 2014). The extracts were filtered, concentrated in a rotary evaporator (Stuart RE3022C, Staffordshire, United Kingdom) $\left(40{ }^{\circ} \mathrm{C}\right)$, frozen and freeze-dried. The extracts obtained were re-dissolved in water:acetone $(6: 4 ; \mathrm{v} / \mathrm{v})$ to a concentration of $50 \mathrm{mg}$ extract $/ \mathrm{mL}$, and preserved by freezing until further analysis. Each extraction treatment was carried out in triplicate.

\subsection{Monomeric anthocyanins, total flavonoids, hydrolysable tannins and total reducing capacity}

The total monomeric anthocyanins, total flavonoids and hydrolysable tannin contents, as well as the total reducing capacity (TRC) of the Centaurea petal extracts (from the control and the dried samples) were determined according to the methodologies used by Fernandes et al. (2017). All determinations were carried out in triplicate. The results for monomeric anthocyanins were expressed in mg cyanidin-3-glucoside/g dry weight (mg Cy 3-glu/g DW), for flavonoids in mg of quercetin equivalent/g DW (mg QE/g DW), for hydrolysable tannins in $\mathrm{mg}$ of tannic acid equivalent/g DW (mg TAE/g DW), and for TRC in $\mathrm{mg}$ gallic acid equivalent/g DW (mg GAE/g DW).

\subsection{Determination of antioxidant activity}

\subsubsection{DPPH (2,2-diphenyl-1-picrylhydrazyl) radical-scavenging activity}

The DPPH radical-scavenging activity was determined by the procedure described by Fernandes et al. (2017) and the antioxidant activity expressed by the percentage of scavenging effect according to Equation 2:
DPPHradicalscavengingeffect $(\%)=\frac{A_{\text {DPPH }}-A_{\text {Sample }}}{A_{\text {DPPH }}} \times 100$

where: $A_{D P P H}$ is the absorbance of the DPPH solution and $A_{\text {sample }}$ the absorbance in the presence of the sample.

The blank was prepared with the solution used in the extraction of the samples. The extract concentration providing $50 \%$ of DPPH radical-scavenging effect $\left(E_{50}\right)$ was calculated from the graph of DPPH radical-scavenging effect percentage versus extract concentration.

\subsubsection{Reducing power}

The reducing power of the extracts was determined using the procedure described by Delgado et al. (2010) and expressed by the $\mathrm{EC}_{50}$ values. These were determined from the graph of $\mathrm{Abs}_{700 \mathrm{~nm}}$ versus extract concentration, corresponding to the concentration that provided an absorbance of 0.5 . Each solution was analysed in triplicate.

\subsection{Statistical analysis}

SPSS Statistic software, version 18.0 (SPSS Inc., Chicago, USA), was used for the statistical treatment of the data. Analyses of variance (ANOVA) or Welch's ANOVA were carried out to evaluate whether there were significant differences $(p<0.05)$ amongst the samples. In addition, significant post-hoc analyses were carried out (Tukey's HSD test if the variances in the different groups were identical or the Games-Howell post-hoc test if they were not). The homogeneity of the variance was evaluated by Levene's test and the correlations between the variables were determined by Pearson's correlation coefficient. The principal component analysis (PCA) was carried out to differentiate Centaurea petals in the fresh state from those subjected to the three drying methods. The variables considered were the WL, $a_{w}, T A, p H$, carotenoids, total reducing capacity, hydrolysable tannins, flavonoids and anthocyanin contents, as well as the $\mathrm{EC}_{50}$ values obtained from the DPPH and reducing power assays.

\section{Results and discussion}

\subsection{Visual appearance}

Figure 1 shows the visual appearance of the fresh versus the dried Centaurea petals. In general, all the dried petals were darker, shrivelled and smaller than the fresh petals. The petals had a different visual appearance as compared to the fresh ones even after short hot-air convective drying periods (1 or 2 hours). No visual differences were perceived amongst the three drying methods, with all the petals presenting similar colours.

\subsection{Physicochemical analyses}

With respect to water activity $\left(a_{w}\right)$, significant differences were found amongst the drying methods (Table 1). The $a_{w}$ values of the dried flowers ranged from 
Effects of different drying methods on the bioactive compounds and antioxidant properties of edible Centaurea (Centaurea cyanus) petals Fernandes, L. et al.

Table 1. Physicochemical properties of Centaurea petals subjected to different drying methods.

\begin{tabular}{|c|c|c|c|c|}
\hline Samples & $\begin{array}{l}\text { Time } \\
\text { (h) }\end{array}$ & $a_{w}$ & $\begin{array}{c}\text { Weight Loss } \\
(\%)\end{array}$ & $\begin{array}{l}\text { Titratable Acidity } \\
\text { (g citric acid/100 g } \\
\text { DW) }\end{array}$ \\
\hline Fresh & -- & $0.97 \pm 0.01^{d}$ & ---- & $0.69 \pm 0.05^{c}$ \\
\hline \multirow{4}{*}{ Hot-air convective dried } & 1 & $0.92 \pm 0.01^{d}$ & $29.8 \pm 1.1^{a}$ & $0.24 \pm 0.05^{a}$ \\
\hline & 2 & $0.90 \pm 0.01^{d}$ & $59.3 \pm 1.5^{b}$ & $0.47 \pm 0.03^{b}$ \\
\hline & 3 & $0.67 \pm 0.05^{c}$ & $72.5 \pm 2.3^{c}$ & $0.53 \pm 0.03^{b, c}$ \\
\hline & 4 & $0.47 \pm 0.01^{b}$ & $73.0 \pm 3.7^{c}$ & $0.66 \pm 0.04^{c}$ \\
\hline Shade-dried & 72 & $0.47 \pm 0.01^{b}$ & $77.8 \pm 6.3^{c}$ & $0.43 \pm 0.03^{b}$ \\
\hline Freeze-dried & 24 & $0.33 \pm 0.01^{\mathrm{a}}$ & $88.0 \pm 0.3^{d}$ & $0.49 \pm 0.05^{b}$ \\
\hline
\end{tabular}

Values are expressed as: Mean \pm Standard deviation. Values with the same letter in the same column are not statistically different $(p>0.05)$.

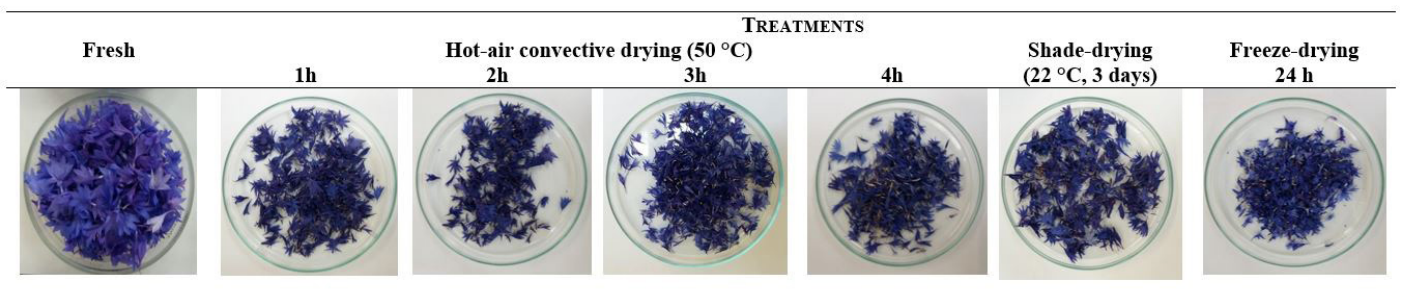

Figure 1. Fresh Centaurea petals and those subjected to three drying methods: hot-air convective drying, shade-drying and freeze-drying.

0.33 (freeze-drying) to 0.92 (hot-air convective drying for 1h). As expected, these values were lower than that of the fresh sample (0.97); however, no significant differences were observed between fresh petals and those subjected to hot-air convective drying for 1 and 2 hours, with the $a_{w}$ only being further reduced by longer exposure to hot-air convective drying. According to Barbosa-Cánovas et al. (2003), pathogenic microorganisms cannot grow at $a_{w}$ values below 0.86 , and yeasts and moulds cannot develop at $a_{w}$ values below 0.62 , but values below these were only reached with hot-air convective drying for 4 hours, shade drying for 72 hours and freeze-drying for 24 hours. Furthermore, a product with an $a_{w}$ of 0.3 will be more stable in relation to enzymatic activity (BARBOSA-CÁNOVAS et al., 2003), but only the freeze-dried flowers showed $a_{w}$ values with this order of magnitude.

With respect to $\mathrm{WL}$, this was more pronounced as a result of freeze-drying (88.0\%), followed by shade drying (77.8\%), and hot-air convective drying for 4 hours $(73.0 \%)$ and 3 hours $(72.5 \%)$.

Regarding TA, the values were reduced by drying from $0.69 \mathrm{~g}$ citric acid/100 g DW (fresh sample) to as low as 0.24 (hot-air convective drying for $1 \mathrm{~h}$ ). The decrease in acidity as a result of drying could be attributed to conversion of the acids into sugars or some other compounds, or the acids might have been used in the respiration process (PRAJAPATI et al., 2011). The application of longer hot-air convective drying periods caused an increase in acidity
(0.24 (1h) to 0.66 (4h) g citric acid/100 g DW), while the shade-dried and freeze-dried samples showed intermediate acidity values $(0.43$ and $0.49 \mathrm{~g}$ citric acid/100 g DW, respectively). No explanation for this variability was found in the literature, indicating that more detailed studies are needed involving the formation of free fatty acids and the transformation of organic acids.

\subsection{Total carotenoids}

A severe loss of total carotenoids was caused in the Centaurea petals by all the drying methods, with significant differences in these losses amongst the drying methods (Table 2). The highest carotenoid contents were found in the hot-air convective dried samples, followed by the shade-dried samples, and the lowest values in the freeze-dried petals. These results were unexpected, and the explanation for the carotenoids losses in the freeze-dried Centaurea petals remains unknown and requires further investigation, as also found for the lycopene content in freeze-dried tomatoes (CHANG et al., 2006).

When comparing the present results with those of Siriamornpun et al. (2012) for marigold flowers, a similar trend was seen, with the higher total carotenoid content being supported by larger amounts of lycopene, $\beta$-carotene and lutein in the case of hot-air convective drying than in the case of freeze-drying. Furthermore, in the present study the fresh flowers presented carotenoid values $(28.1 \mu \mathrm{g} \beta$-carotene/g DW) approximately three times higher than those of the dried 


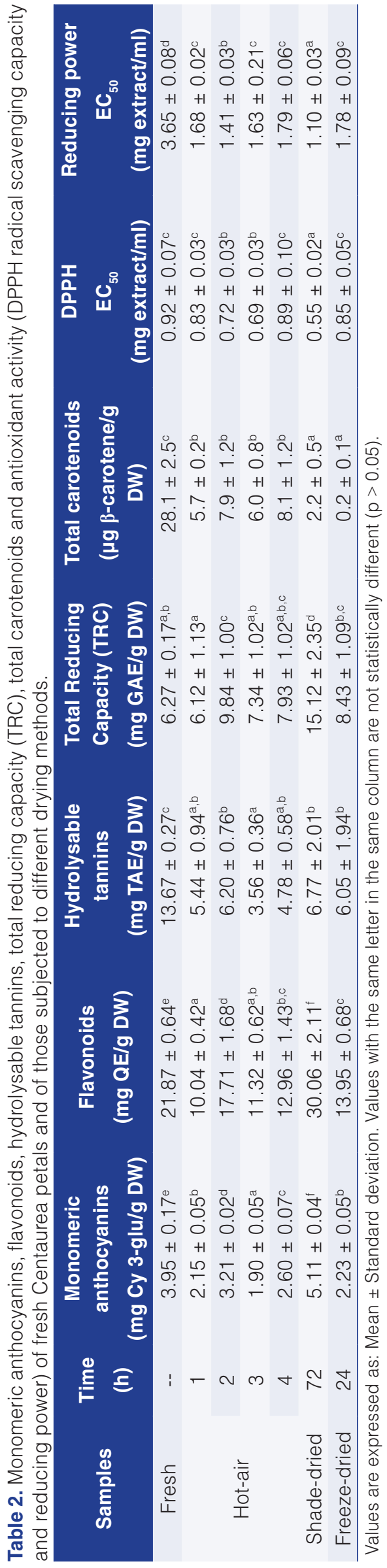


flowers (less than $10 \mu \mathrm{g} \beta$-carotene/g DW). The results of this study suggest that drying, when applied to flowers, may cause carotenoid degradation. Carotenoids are thermally labile (MURATORE et al., 2008) and unstable at low water activity values (LAVELLI et al., 2007).

\subsection{Monomeric anthocyanins}

The total monomeric anthocyanin contents of the Centaurea petals subjected to different drying methods varied significantly according to the method used (Table 2), ranging from 1.90 (hot-air convective drying for $3 \mathrm{~h}$ ) to $5.11 \mathrm{mg}$ Cy $3-\mathrm{glu} / \mathrm{g}$ DW (shade drying), with values for the fresh petals of $3.95 \mathrm{mg}$ Cy $3-\mathrm{glu} / \mathrm{g}$ DW. Almost all the hot-air dried samples presented the lowest monomeric anthocyanin content, probably due to the high temperatures used and high oxygen concentrations involved in this type of drying, leading to rapid degradation of the anthocyanins (PIGA et al., 2003). However, higher values were determined after $4 \mathrm{~h}$ than after $3 \mathrm{~h}$ for hot-air convective drying. This might be a consequence of the balance achieved between the drying temperature and time or due to the transformation of polyphenols (including anthocyanins) from the bound state to the free state, which may occur at high temperatures after long periods (ZHENG et al., 2015). Apart from the heat, a number of other factors such as light, temperature and storage conditions can also be responsible for the anthocyanin degradation during drying (SHAHIDI; NACZK, 2004). Since shade drying does not imply in the use of high temperatures and exposure to light is limited, these factors may explain the higher preservation of the anthocyanins when using this method.

\subsection{Total flavonoids}

Table 2 shows the total flavonoid contents of the Centaurea petals subjected to the different drying methods. Once again the hot-air dried samples presented the lowest concentrations, those dried with hot air for only $1 \mathrm{~h}$ showing the lowest amount (10.04 mg QE/g DW), corresponding to $46 \%$ of the content determined in the fresh samples (21.87 $\mathrm{mg} \mathrm{QE} / \mathrm{g} \mathrm{DW}$ ). These results are in agreement with those of Piga et al. (2003), who found that hot-air drying may lead to a significant decrease in flavonoids. On the other hand the shade-dried petals presented the highest flavonoid concentration (30.06 mg QE/g DW) and freeze-drying caused flavonoid losses of approx. $36 \%$ in comparison with the fresh petals.

\subsection{Hydrolysable tannins}

Significant differences were detected between the different drying methods with respect to the hydrolysable tannin content (Table 2), ranging from 3.56 to $6.77 \mathrm{mg}$ TAE/g DW for hot-air convective drying for $3 \mathrm{~h}$ and shade drying, respectively. However, the highest values, at least twice the amount, were observed in the fresh samples (13.67 mg TAE/g DW). These findings were similar to those of Salminen (2003), who reported lower values for hydrolysable tannins in birch leaves (Betula pubescens Ehrh.), dried in an oven $\left(60^{\circ} \mathrm{C}\right.$ for $\left.12 \mathrm{~h}\right)$ $(11.58 \mathrm{mg} / \mathrm{g} \mathrm{DW})$ than in those dried in a fume hood at room temperature for 4 days $(14.14 \mathrm{mg} / \mathrm{g} \mathrm{DW})$ and in the freeze-dried (48 h) leaves ( $15.35 \mathrm{mg} / \mathrm{g} \mathrm{DW})$. Moreover, the room temperature air-dried and freeze-dried samples were not different (SALMINEN, 2003), as also observed in the present work.

\subsection{Total reducing capacity}

Regarding the total reducing capacity (TRC) of Centaurea petals subjected to the different drying methods, the values varied between 6.12 and $15.12 \mathrm{mg} \mathrm{GAE} / \mathrm{g}$ DW (Table 2). The highest TRC was recorded for petals dried at room temperature (shade-dried), 1.26 times higher than the fresh petals. All the dried samples, with the exception of the hot-air convective samples dried for $1 \mathrm{~h}$, had higher mean values for TRC than the fresh samples, although some cases were not significantly different. This is in agreement with the results of Suvarnakuta et al. (2011), who reported that dried plant materials contained larger amounts of antioxidants, such as polyphenolic compounds, than the fresh plant materials. Dehydration treatments may release bound phytochemicals (e.g., phenolic compounds) from the matrix, making them more accessible to extraction (WOJDYŁO et al., 2014). In addition, the intercellular spaces of the tissues may collapse, liberating more bioactive secondary metabolites such as polyphenolic compounds (DI CESARE et al., 2003; YOUSIF et al., 1999). Furthermore, Suhaj (2006) suggested that some of the bioactive compounds in the fresh samples might be unstable or degraded by enzymatic action, suggesting the use of dried samples.

When comparing hot-air convective drying with freeze-drying, no significant differences were observed between the methods, with the exception of $1 \mathrm{~h}$ convective drying, results that differed from those of Siriamornpun et al. (2012), Mao et al. (2006) and Zheng et al. (2015) for marigold, daylily and loquat flowers, respectively. These authors found higher values for TRC after freeze-drying than after hot-air convective drying. However, the hot-air drying conditions applied by those authors were different from those used in the present study, namely, $60{ }^{\circ} \mathrm{C}$ for $4 \mathrm{~h}$ (SIRIAMORNPUN et al., 2012), $55^{\circ} \mathrm{C}$ for $24 \mathrm{~h}$ (MAO et al., 2006), and $40^{\circ} \mathrm{C}$ or $60^{\circ} \mathrm{C}$ for $8 \mathrm{~h}$ or $5 \mathrm{~h}$, respectively (ZHENG et al., 2015). Thus higher temperatures and longer drying times were used in these studies as compared to those used in the present work. Since phenolic compounds are sensitive to heat, an increase in temperature may result in a significant loss of these compounds (LIN et al., 2011). 


\subsection{Antioxidant activity}

\subsubsection{DPPH (2,2-diphenyl-1-picrylhydrazyl) radical-scavenging activity}

Table 2 shows the DPPH scavenging activities of the Centaurea petals dried by the methods used in the present work. The shade-dried samples presented the highest antioxidant activity, with the lowest $\mathrm{EC}_{50}$ values for DPPH (0.55 mg extract $/ \mathrm{mL}$ ), while the fresh, freeze-dried and hot-air dried samples for $1 \mathrm{~h}$ and $4 \mathrm{~h}$ showed higher $\mathrm{EC}_{50}$ values. These results corroborate with the previous analysis, showing that the shade-drying method resulted in petals with higher DPPH radical-scavenging activity than the other drying methods. The present results were similar to those reported by Pinela et al. (2012) for Tuberaria lignosa (Sweet) Samp, who observed that infusions of shade-dried samples showed the highest DPPH radical-scavenging activity and reducing power as compared to infusions of freeze-dried and fresh samples. Furthermore, the present study showed that hot-air drying for $2 \mathrm{~h}$ and $3 \mathrm{~h}$ (0.72 and $0.69 \mathrm{mg}$ extract $/ \mathrm{mL}$, respectively) produced samples with higher DPPH radical-scavenging activities than freeze-drying $(0.85 \mathrm{mg}$ extract $/ \mathrm{mL})$. These results were different from those obtained with daylily flowers, where the water and ethanol extracts from freeze-dried flowers showed higher DPPH scavenging activities than those prepared from hot-air dried samples (MAO et al., 2006), and also for those prepared from marigold, where the freeze-dried and fresh petals showed higher DPPH scavenging activities (67\% and $65 \%$, respectively) than those dried with hot air (52.4\%), for a $0.1 \mathrm{mg} / \mathrm{mL}$ extract solution (SIRIAMORNPUN et al., 2012). However, these different results in relation to the present results can be explained by the different times and temperatures used in both studies. In the first study, the flowers were treated at $55^{\circ} \mathrm{C}$ for $24 \mathrm{~h}$ (hot-air dried) and for $12 \mathrm{~h}$ (freeze-dried), and in the second study at $60{ }^{\circ} \mathrm{C}$ for $4 \mathrm{~h}$ (hot-air dried) and for $48 \mathrm{~h}$ (freeze-dried). Thus the application of different drying conditions and methods significantly influences the DPPH scavenging activities of dried petals.

\subsubsection{Reducing power}

With respect to reducing power, significant differences were detected (Table 2). The $\mathrm{EC}_{50}$ values ranged between 1.10 and $3.65 \mathrm{mg}$ extract $/ \mathrm{mL}$ for shade-dried and fresh petals, respectively and hence the shade-dried samples presented the highest reducing power, since they had the lowest $\mathrm{EC}_{50}$ value. In addition, the reducing power values of hot-air convective dried petals ( $1 \mathrm{~h}, 3 \mathrm{~h}$ and $4 \mathrm{~h}$ ) were not significantly different from those of freeze-dried petals. However, all these $\mathrm{EC}_{50}$ values were lower than those of the fresh samples, suggesting that drying increased the antioxidant activity in terms of the reducing power of the petals.

\subsection{Correlations between total reducing capacity, monomeric anthocyanins, flavonoids, hydrolysable tannins, and antioxidant activity}

The Pearson correlation coefficients determined between the TRC, monomeric anthocyanins, flavonoids, hydrolysable tannins and antioxidant activity $\left(\mathrm{EC}_{50}\right.$ values of DPPH and reducing power assays) are presented in Table 3. Significant positive correlations were found between the TRC and monomeric anthocyanins (0.668), as well as between the TRC and the flavonoids (0.737), showing the important role of these compounds in the TRC. As expected, negative correlations were detected between the TRC and the $\mathrm{EC}_{50}$ values of DPPH $(-0.751)$ and reducing power $(-0.531)$, since these properties are inversely correlated. The flavonoids also presented a positive correlation with the monomeric anthocyanins (0.965), since anthocyanins are a subclass of flavonoids.

Concerning the antioxidant activity, a significant negative correlation was found between the flavonoids and the $\mathrm{EC}_{50} \mathrm{DPPH}$ values (-0.502), related to the antioxidant potential of these compounds. Moreover, a significant negative correlation was found between the $\mathrm{EC}_{50} \mathrm{DPPH}$ and monomeric anthocyanins (-0.402), demonstrating their role in the DPPH free-radical scavenging effect.

\subsection{Principal component analysis}

The principal component analysis (PCA) was applied to classify the fresh and dried samples into groups. Figure 2 shows the scores of the first two principal components for the Centaurea petals subjected to the three different drying treatments. The first two principal components explained $88.5 \%$ of the total variation

Table 3. Pearson correlation coefficients for the total reducing capacity, monomeric anthocyanins, flavonoids, hydrolysable tannins and $\mathrm{EC}_{50}$ values of the $\mathrm{DPPH}$ and Reducing Power assays.

\begin{tabular}{|c|c|c|c|c|c|}
\hline & $\begin{array}{c}\text { Monomeric } \\
\text { anthocyanins }\end{array}$ & Flavonoids & $\begin{array}{l}\text { Hydrolysable } \\
\text { tannins }\end{array}$ & $E_{50}$ DPPH & $\begin{array}{c}\text { EC }_{50} \text { Reducing } \\
\text { Power }\end{array}$ \\
\hline Total reducing capacity & $0.668^{\star \star}$ & $0.737^{\star *}$ & -0.065 & $-0.751^{\star \star}$ & $-0.531^{\star \star}$ \\
\hline Monomeric anthocyanins & -__ & $0.965^{\star \star}$ & $0.510^{\star \star}$ & $-0.402^{\star *}$ & 0.087 \\
\hline Flavonoids & $\ldots$ & -_- & $0.491^{\star *}$ & $-0.502^{\star \star}$ & 0.042 \\
\hline Hydrolysable tannins & $\ldots$ & $\ldots$ & _- & 0.302 & $0.787^{\star \star}$ \\
\hline $\mathrm{EC}_{50} \mathrm{DPPH}$ & - & - & - & - & $0.650^{* \star}$ \\
\hline
\end{tabular}

Correlation is significant at ${ }^{* *} p<0.01$ 


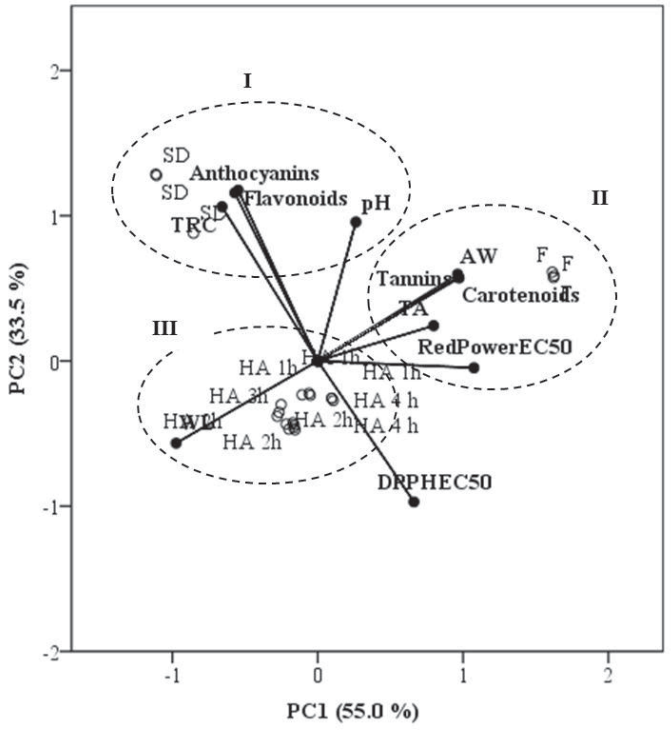

Figure 2. Principal component analysis plot of fresh (F) Centaurea petals and of those dried by the following methods: hot-air convective drying (HA), freeze-drying (FD) and shade-drying (SD). Principal component 1 (PC1), Principal component 2 (PC2), total reducing capacity (TRC), water activity (AW), weight loss (WL).

$(\mathrm{PC} 1=55.0 \%$ and $\mathrm{PC} 2=33.5 \%$, respectively). $\mathrm{PC} 1$ was mainly correlated positively to the hydrolysable tannins, carotenoids, $\mathrm{EC}_{50}$ values of the reducing power, TA and $a_{w}$, and negatively to WL. PC2 was highly correlated to the monomeric anthocyanins, TRC, flavonoids and $\mathrm{pH}$, and negatively to the $\mathrm{EC}_{50}$ values of the DPPH assay. Three groups were obtained. Group I was formed by the shade-dried flowers (SD), with high scores in PC2 due to the high values of the monomeric anthocyanin contents, TRC and flavonoids. With respect to the fresh petals (F), corresponding to Group II, these samples presented the highest hydrolysable tannins and carotenoid contents, $T A$ and $E_{50}$ values of the reducing power, whereas the hot-air dried and freeze-dried samples (Group III) showed the highest $\mathrm{WL}$ and $\mathrm{EC}_{50}$ values of the $\mathrm{DPPH}$, indicating lower antioxidant activity.

\section{Conclusion}

The results of this study show that each drying method produces different effects on the physicochemical properties and bioactive compounds of Centaurea petals. In general, drying produced darker, shrivelled and smaller flowers with lower TA values and carotenoid and hydrolysable tannin contents than fresh flowers, while increasing their total reducing capacity and antioxidant activity in terms of reducing power. The highest carotenoid content was identified in hot-air convective dried samples, but this method produced the lowest anthocyanin and flavonoid contents, while the shade-dried samples presented the highest values for both compound classes. The shade-dried samples also presented the highest TRC, DPPH radical-scavenging activity and reducing power, and one of the lowest $\mathrm{a}_{w}$ values. In summary, the present study has provided useful information on the industrial drying processes of Centaurea petals, showing the advantages of shade drying at room temperature, which is a sustainable and green technology with low energy costs.

\section{References}

ABASCAL, K.; GANORA, L.; YARNELL, E. The effect of freezedrying and its implications for botanical medicine: a review. Phytotherapy Research, v. 19, n. 8, p. 655-660, 2005. http:// dx.doi.org/10.1002/ptr.1651. PMid:16177965.

AQUINO-BOLAÑOS, E. N.; URRUTIA-HERNÁNDEZ, T.; CASTILLOLOZANO, M. L. D.; CHAVÉZ-SERVIA, J.; VERDALET-GUZMÁN, I. Physicochemical parameters and antioxidant compounds in edible squash (Cucurbita pepo) flower stored under controlled atmospheres. Journal of Food Quality, v. 36, n. 5, p. 302-308, 2013. http://dx.doi.org/10.1111/jfq. 12053.

BALLADIN, D. A.; HEADLEY, O. Evaluation of solar dried thyme (Thymus vulgaris Linné) herbs. Renewable Energy, v. 17, n. 4, p. 523-531, 1999. http://dx.doi.org/10.1016/S0960-1481(98)00757-5.

BARBOSA-CÁNOVAS, G. V.; FERNÁNDEZ-MOLINA, J. J.; ALZAMORA, S. M.; TAPIA, M. S.; LÓPEZ-MALO, A.; CHANES, J. W. In: FOOD AND AGRICULTURE ORGANIZATION - FAO. (Ed.). General considerations for preservation of fruits and vegetables: handling and preservation of fruits and vegetables by combined methods for rural areas. Rome: FAO, 2003. p. 39-54.

BATRAS, A. To study the behaviour of colour change in some dehydrated ornamental flowers. International Journal of Latest Research in Science and Technology, v. 4, n. 4, p. 141-144, 2015.

BOLAND, F. E.; CUNNIFF, P. (Ed.). Official methods of analysis of the Association of Official Analytical Chemists: method 940.26: ash of fruits and fruit products. Arlington: AOAC, 1999.

CHAITANYA, L. G. Food coloring: the natural way. Research Journal of Chemical Sciences, v. 4, n. 2, p. 87-96, 2014.

CHANG, C.-H.; LIN, H.-Y.; CHANG, C.-Y.; LIU, Y.-C. Comparisons on the antioxidant properties of fresh, freeze-dried and hot-airdried tomatoes. Journal of Food Engineering, v. 77, n. 3, p. 478-485, 2006. http://dx.doi.org/10.1016/j.jfoodeng.2005.06.061.

CHEN, W.; GAST, K.; SMITHEY, S. The effects of different freezedrying processes on the moisture content, color and physical strength of roses and carnations. Scientia Horticulturae, $v$. 84, n. 3-4, p. 321-332, 2000. http://dx.doi.org/10.1016/S03044238(99)00106-5.

CHIRU, T. Phytochemical study of Centaurea Cyanus L. USAMV Bucharest, Series A, v. 52, p. 293-297, 2009.

DELGADO, T.; MALHEIRO, R.; PEREIRA, J. A.; RAMALHOSA, E. Hazelnut (Corylus avellana L.) kernels as a source of antioxidants 
Effects of different drying methods on the bioactive compounds and antioxidant properties of edible Centaurea (Centaurea cyanus) petals Fernandes, L. et al.

and their potential in relation to other nuts. Industrial Crops and Products, v. 32, n. 3, p. 621-626, 2010. http://dx.doi.org/10.1016/j. indcrop.2010.07.019

DI CESARE, L. F.; FORNI, E.; VISCARDI, D.; NANI, R. Changes in the chemical composition of Basil caused by different drying procedures. Journal of Agricultural and Food Chemistry, v. 51, n. 12, p. 3575-3581, 2003. http://dx.doi.org/10.1021/jf021080o. PMid: 12769527

FERNANDES, L.; CASAL, S. I.; PEREIRA, J. A.; RAMALHOSA, E.; SARAIVA, J. Optimization of high pressure bioactive compounds extraction from pansies (Viola $\times$ wittrockiana) by response surface methodology. High Pressure Research, v. 37, n. 3, p. 415-429, 2017. http://dx.doi.org/10.1080/08957959.2017.1347925.

GAITHERSBURG, G. L.; HORWITZ, W. K. (Ed.). Official methods of analysis of the Association of Official Analytical Chemists. Arlington: AOAC, 1990

HAMROUNI-SELLAMI, I.; RAHALI, F. Z.; REBEY, I. B.; BOURGOU, S.; LIMAM, F.; MARZOUK, B. Total Phenolics, flavonoids, and antioxidant activity of sage (Salvia officinalis L.) plants as affected by different drying methods. Food and Bioprocess Technology, v. 6, n. 3, p. 806-817, 2013. http://dx.doi.org/10.1007/s11947012-0877-7.

JI, H.-F.; DU, A.-L.; ZHANG, L.-W.; XU, C.-Y.; YANG, M.-D.; $L I, F .-F$. Effects of drying methods on antioxidant properties in Robinia pseudoacacia L. flowers. Journal of Medicinal Plants Research, v. 6, n. 16, p. 3233-3239, 2012.

KIM, H.-O.; DURANCE, T. D.; SCAMAN, C. H.; KITTS, D. D. Retention of caffeic acid derivatives in dried Echinacea purpurea. Journal of Agricultural and Food Chemistry, v. 48, n. 9, p. 41824186, 2000. http://dx.doi.org/10.1021/jf000245v. PMid:10995334.

KOU, L.; TURNER, E. R.; LUO, Y. Extending the shelf life of edible flowers with controlled release of 1-Methylcyclopropene and modified atmosphere packaging. Journal of Food Science, v. 77, n. 5, p. 188-193, 2012. http://dx.doi.org/10.1111/j.17503841.2012.02683.x. PMid:23163949

LAVELLI, V.; ZANONI, B.; ZANIBONI, A. Effect of water activity on carotenoid degradation in dehydrated carrots. Food Chemistry, v. 104, n. 4, p. 1705-1711, 2007. http://dx.doi.org/10.1016/j. foodchem.2007.03.033.

LI, A.-N.; LI, S.; LI, H.-B.; XU, D.-P.; XU, X.-R.; CHEN, F. Total phenolic contents and antioxidant capacities. Journal of Functional Foods, v. 6, p. 319-330, 2014. http://dx.doi. org/10.1016/j.jff.2013.10.022

LIM, T. K. Edible medicinal and non medicinal plants. Dordrecht: Springer, 2014

LIN, S.-D.; SUNG, J.-M.; CHEN, C.-L. Effect of drying and storage conditions on caffeic acid derivatives and total phenolics of Echinacea purpurea grown in Taiwan. Food Chemistry, v. 125 , n. 1, p. 226-231, 2011. http://dx.doi.org/10.1016/j. foodchem.2010.09.006.
MAO, L.-C.; PAN, X.; QUE, F.; FANG, X.-H. Antioxidant properties of water and ethanol extracts from hot air-dried and freeze-dried daylily flowers. European Food Research and Technology, v. 222, n. 3-4, p. 236-241, 2006. http://dx.doi.org/10.1007/s00217005-0007-0.

MURATORE, G.; RIZZO, V.; LICCIARDELLO, F.; MACCARONE, E. Partial dehydration of cherry tomato at different temperature, and nutritional quality of the products. Food Chemistry, v. 111, n. 4, p. 887-891, 2008. http://dx.doi.org/10.1016/j.foodchem.2008.05.001.

PIGA, A.; DEL CARO, A.; CORDA, G. From plums to prunes: Influence of drying parameters on polyphenols and antioxidant activity. Journal of Agricultural and Food Chemistry, v. 51, n. 12, p. 3675-3681, 2003. http://dx.doi.org/10.1021/jf021207+. PMid: 12769544

PINELA, J.; BARROS, L.; DUEÑAS, M.; CARVALHO, A. M.; SANTOS-BUELGA, C.; FERREIRA, I. C. Antioxidant activity, ascorbic acid, phenolic compounds and sugars of wild and commercial Tuberaria lignosa samples: effects of drying and oral preparation methods. Food Chemistry, v. 135, n. 3, p. 10281035, 2012. http://dx.doi.org/10.1016/j.foodchem.2012.05.038.

PRAJAPATI, V. K.; NEMA, P. K.; RATHORE, S. S. Effect of pretreatment and drying methods on quality of value-added dried aonla (Emblica officinalis Gaertn) shreds. Journal of Food Science and Technology, v. 48, n. 1, p. 45-52, 2011. http://dx.doi.org/10.1007/s13197-010-0124-z. PMid:23572715.

SADLER, M. J. Dried fruit and dental health. International Journal of Food Sciences and Nutrition, v. 67, n. 8, p. 944-959, 2016. http://dx.doi.org/10.1080/09637486.2016.1207061. PMid:27415591.

SALMINEN, J.-P. Effects of sample drying and storage, and choice of extraction solvent and analysis method on the yield of birch leaf hydrolyzable tannins. Journal of Chemical Ecology, v. 29, n. 6, p. 1289-1305, 2003. http://dx.doi.org/10.1023/A:1024249016741. PMid: 12918916

SHAHIDI, F.; NACZK, M. Phenolics in food and nutraceuticals. Boca Raton: CRC Press, 2004.

SIRIAMORNPUN, S.; KAISOON, O.; MEESO, N. Changes in colour, antioxidant activities and carotenoids (lycopene, $\beta$-carotene, lutein) of marigold flower (Tagetes erecta L.) resulting from different drying processes. Journal of Functional Foods, v. 4, n. 4, p. 757-766, 2012. http://dx. doi.org/10.1016/j.jff.2012.05.002.

SUHAJ, M. Spice antioxidants isolation and their antiradical activity: a review. Journal of Food Composition and Analysis v. 19, n. 6-7, p. 531-537, 2006. http://dx.doi.org/10.1016/j. jfca.2004.11.005.

SUVARNAKUTA, P.; CHAWEERUNGRAT, C.; DEVAHASTIN, S. Effects of drying methods on assay and antioxidant activity of xanthones in mangosteen rind. Food Chemistry, v. 125, n. 1, p. 240-247, 2011. http://dx.doi.org/10.1016/j.foodchem.2010.09.015.

TAI, C.-Y.; CHEN, B. H. Analysis and stability of carotenoids in the flowers of daylily (Hemerocallis disticha) as affected by various 
Effects of different drying methods on the bioactive compounds and antioxidant properties of edible Centaurea (Centaurea cyanus) petals Fernandes, L. et al.

treatments. Journal of Agricultural and Food Chemistry, v. 48, n. 12, p. 5962-5968, 2000. http://dx.doi.org/10.1021/jf000956t. PMid:11312769.

WOJDYŁO, A.; FIGIEL, A.; LECH, K.; NOWICKA, P.; OSZMIA SKI, $J$. Effect of convective and vacuum-microwave drying on the bioactive compounds, color, and antioxidant capacity of sour cherries. Food and Bioprocess Technology, v. 7, n. 3, p. 829-841, 2014. http://dx.doi.org/10.1007/s11947-013-1130-8.
YOUSIF, A. N.; SCAMAN, C. H.; DURANCE, T. D.; GIRARD, B. Flavor volatiles and physical properties of vacuum-microwaveand air-dried sweet basil (Ocimum basilicum L.). Journal of Agricultural and Food Chemistry, v. 47, n. 11, p. 4777-4781, 1999. http://dx.doi.org/10.1021/jf990484m. PMid:10552889.

ZHENG, M.; XIA, Q.; LU, S. Study on drying methods and their influences on effective components of loquat flower tea. Lebensmittel-Wissenschaft + Technologie, v. 63, n. 1, p. 14-20, 2015. http://dx.doi.org/10.1016/j.Iwt.2015.03.090. 